NBER WORKING PAPER SERIES

UNIONS AND EQUAL EMPLOYMENT OPPORTUNITY

Jonathan S. Leonard

Working Paper No. 1311

NATIONAL BUREAU OF ECONOMIC RESEARCH

1050 Massachusetts Avenue

Cambridge, MA 02138

March 1984

This work was supported in part by the Office of the Assistant Secretary for Policy Evaluation of the U.S. Department of Labor, and by the Institute of Industrial Relations and School of Business Administration, University of California at Berkely. The research reported here is part of the NBER's research program in Labor Studies. Any opinions expressed are those of the author and not those of the Department of Labor, University of California or the National Bureau of Economic Research. 
NBER Working Paper \#1311 March 1984

\section{Unions and Equal Employment opportunity}

\section{ABSTRACT}

This paper analyzes differences in the growth of minority and female employment between union and non-union manufacturing plants in California during the late 1970 's. In this sector, unionized plants do not exhibit any more gross employment discrimination than do non-union plants against black or Hispanic men, or against black or white women, despite the recessions of the 1970 's that displaced low seniority workers. Black males actually enjoy faster growth of employment share in unionized plants, suggesting that Title VII has been effective in increasing opportunities for blacks. This may help explain why unionization, though decreasing in the private sector, has been increasing among blacks. The role played by unions in mediating affirmative action regulations is also examined.

There are significant differences across particular unions, especially between craft and industrial unions, within industries that correspond with each union's public record on EEO. Black employment increases most rapidly in industries with a long history of black employment, in plants organized by unions that take a liberal position towards EEO, and in industries with a large union wage effect. As least in California manufacturing during this period, the belief that unions have hindered minority and female employment does not seem to hold true for industrial unions.

Jonathan S. Leonard 350 Barrows Hall Schools of Business Administration University of California at Berkeley Berkeley, CA 94720 
How harmful or helpful have unions been to the employment interests of minorities and females? In the political sphere, the AFL-CIO has often joined with blacks and females in a familiar coalition. In the workplace, these groups have not been able to forge a unity of interest. Open conflicts, including litigation and demonstrations, have often emerged at the local level.

This paper asks one main question: what impact have unions had on the employment of minorities and females in manufacturing? To determine whether minority and fernale employment has been helped or hindered by unionism, the change during the late 1970's in the employment of male and female Hispanics, blacks, whites and Asians is compared across union and non-union plants.

Two secondary issues are also addressed. First, how have unions mediated affirmative action pressure? The success of federal policies to improve employment opportunities for minorities and females depends not only on the response of employers, as this problem has usually been modeled, but also on that of unions. The study of the impact of federal anti-discrimination and affirmative action regulation is still young, and has yet to seriously address the role played by unions in mediating regulatory pressure ${ }^{1}$. Union seniority provisions came into sharp conflict with equal employment opportunity policy during the stagnant seventies. While this provoked many anecdotes and law cases, the actual impact on employment of this conflict involving federal, corporate, and union policy has never been studied with the attention it deserves.

Second, why has unionization increased so dramatically among blacks at the same time that private sector unionism is in decline? The study design here isolates from the confounding effects of regional, industry or establishment growth, directly controls for affirmative action pressure, and attempts to separate individual union, establishment and demographic group effects in explaining this growth.

This study analyzes a new and detailed longitudinal set of data on 1273 California 
manufacturing establishments between 1974 and 1980. The ethnic diversity of this state provides informative contrasts across Hispanics, Asians, blacks and whites. The analysis proceeds in five stages. First, we establish the expected roles played by unions, firms, demographic groups, and the government within the framework of a model of the supply and demand for union and non-union labor. Second, we estimate the mean difference in demographic changes in employment between union and nonunion plants using both $T$-tests across means and weighted log-odds regressions, and find that in the late 1970 's blacks' employment share increases faster in the union sector. Third, to isolate a general proclivity toward unionism among minorities or females from the behavior of unions themselves, we exploit the distribution of unions across establishments and industries to estimate differences across individual unions in minority and female employment growth. Fourth, to test for spillover and omitted variable bias, employment patterns among white-collar workers are also studied. The interaction of affirmative action with unionism is analyzed in the fifth section, and our conclusions are summarized in the final section.

The goal here is to open a new level of empirical research on the question of the impact of unionization on minority and female employment. The central finding is that unions have not been a significant detriment to the employment of minorities or females.

\section{Section 1. Background}

Why should the unionized sector in manufacturing be any different than its nonunion counterpart in its employment of Hispanics, blacks, Asians, and women? In broadest terms, there are four major actors whose policies and preferences are of immediate concern. These are the unions, the companies, the demographic groups, and the federal government. In this section, we shall first place each of these actors within a model of minority and female employment, and then proceed to discuss their expected roles. 
The demand for labor may usefully be thought of as:

$$
L_{i j}=f\left(U_{i}, S_{i}, F_{i j}, D_{i j}, W_{j}\right)
$$

where

$$
\begin{aligned}
L_{i j}^{D} & =\text { demand for labor of demographic group j by firm i } \\
U & =\text { unionization } \\
S & =\text { skill requirements } \\
F & =\text { federal anti-discrimination and affirmative action pressure } \\
D & =\text { firm tastes for discrimination } \\
W & =\text { wage }
\end{aligned}
$$

The supply of labor is given by:

$$
L_{i j}^{S}=F\left(G_{i j}, S_{j}, T_{i j}, W_{j}\right)
$$

where

$\mathrm{G}=$ geographic commuting cost

$\mathrm{S}=$ skill availability

$\mathrm{T}=$ average group preferences

This model is presented chiefly to structure the following discussion of expected impact and paths. We shall return to it again at the end of this section to set up empirical tests that isolate union, demographic group, establishment, and government effects.

\section{The Role of Unions}

The first impulse is to ascribe differences between the union and non-union sectors to the policies and practices of the unions themselves. The most obvious way unions can affect the demographic composition of the workforce is by directly 
controlling hiring. The key distinction here is between craft and industrial unions, or more precisely and tautologically, between referral and non-referral unions. Under Landrum-Griffn, construction unions have what is in practice a closed shop with the union often controlling who may be hired. The broad scope this gives to discrimination is revealed in studies which show evidence of discrimination against blacks in the unionized construction trades, but not in other unionized occupations. As the history of the construction, longshoring, maritime and printing trades shows, the legal restrictions on unions' control of hiring are not always honored in practice. In California manufacturing, typically thought of as non-referral, it is not uncommon to find modified referral clauses in collectively bargained contracts. Typically, the company agrees to notify the union first when a job opens ${ }^{2}$. The question of referral practices in the unions is an empirical one that cannot be resolved by reference to contractual provisions or labor law. While the substantial differences between construction craft unions and others is universally acknowledged, there is no evidence that rules out the power of unions in the manufacturing sector to influence the hiring decisions of employers.

If, as seems reasonable, we grant the unions in manufacturing some influence, then their attitudes become important, and these attitudes are strongly shaped by circumstances ${ }^{3}$. To bargain effectively an industrial union must organize enough of its industry to reduce the elasticity of demand for union labor. Unions faced with an industry employing substantial numbers of blacks or females have typically found it in their hearts to take a more liberal stand toward the employment and organizing of such potential competitors. (Ashenfelter 1973, Fogel, Marshall). But these crossindustry patterns cannot easily explain the relative prevalence of blacks, for example, in union plants within an industry. Differences are relative, so an egalitarian union may appear angelic next to a discriminating non-union sector. But the historical record shows unions following, and forced to adapt to the relative lack of discrimina- 
tion in the non-union sector. (Marshall, Fogel).

Seniority is one of the ruling principles of industrial unionism. It is well known that quit rates are much lower in the union sector, in response to strong seniority benefits, high compensation, and the union voice mechanism. (Block, Freeman). This in itself will tend to freeze the workforce and slow the entry of any previously discriminated against group, a point we shall return to in Section 5 . So even in the absence of current discrimination, we would expect minorities and females to make slower progress in increasing their share of employment in the union sector.

Since 1965 the courts have often struggled with the problem raised by facially neutral seniority systems that lock in the effects of past discrimination. The conflict between union seniority clauses and federal anti-discrimination and affirmative action policy has been painfully exposed by recent recessions when last-in first-out union seniority clauses have helped undo years of federal pressure to increase minority and female employment. The problem has been exacerbated by the unionized sector's tendency to resort to layoffs during a downturn. (Medoff). The Supreme Court in its 1977 Teamsters decision overruled a series of lower court decisions in which seniority systems had come under attack for freezing out a generation of blacks. ${ }^{4}$ This ruling gave greater weight to Section $703(\mathrm{~h})$ of the Civil Rights Act of 1964, largely insulating seniority units that are created and administered in a non-discriminatory fashion from charges of locking in pre-1965 discrimination. An employer who might be successfully sued under Title VII for his low representation of females or minorities is largely immunized from such suit if this underrepresentation is due to the functioning of a seniority system that has been non-discriminatory in intent and administration since 1965 .

We would expect then that during the late seventies minorities and females would make smaller employment gains in the union sector, both because union seniority systems reduce workforce turnover, and because such systems tend to insulate the firm 
from Title VII damages.

Unions' attitudes toward minorities and females may also be influenced by their desire to maintain one rate of pay for each job no matter who holds it, and by the contingencies of liberal coalition politics at the national level. But it is a long road down to the locals, which respond more closely to their own local problems than to the noble words of their national leaders. (Marshall). While the nationals have some concern with maintaining the union's share of an industry, the locals have typically taken a more exclusionary stand.

\section{The Role of the Federal Government}

The protection afforded unionized plants under Section 703(h) of Title VIl has already been noted. The other arm of federal policy in this arena is affirmative action regulation under Executive Order 11246 and its successors. This pressure is directed towards federal contractors, not directly against unions in the manufacturing sector. The legal limits of such compulsion are largely circumscribed by reference to Title VII, so the same judicial interpretations that immunize unionized establishments under Title VII tend also to insulate them from affirmative action pressure.

Unionized establishments are more likely than their non-union counterparts to be federal contractors in the study sample. A more important finding is that among contractors, union plants are not any more likely to undergo a compliance review, the chief affirmative action enforcement procedure. While there are major cases in the past of the government setting out after construction unions, most notably in the Philadelphia Plan and its progeny, the government appears to be largely neutral between the union and non-union sectors of manufacturing.

\section{The Employers}

There seems little reason to expect unionized employers to act differently, ceteris paribus, in their employment of minorities and females for reasons other than the 
indirect influence of the unions or the government mentioned above, or the direct impact of the union wage effect. Unions have been estimated to raise wages by 15 to 20 percent in the manufacturing sector, (Lewis). This will tend to reduce employment in the unionized sector and may work against minorities or females in hiring if they are less skilled. But it is not clear that these groups are any less productive than whites in ways that are material to manufacturing. (Leonard). In addition, unionized plants tend to be larger, and are more likely to be part of a multi-plant corporation. These two factors, along with the fact of unionization itself, contribute to more for-1 malized personnel procedures that may reduce discrimination.

\section{Demographic Group Differences}

The relative employment of blacks may be greater in the union sector than in the non-union sector not because of the preferences of the unions, the government, or the employers, but rather because of the preferences of blacks themselves. In a number of studies during the 1970's, blacks are reported to have much stronger preferences than whites for unions. (Farber and Saks, Freeman and Medof, Kochan). The evidence is less clear on preferences among women and Hispanics. This need not imply that blacks have different utility functions, but rather that blacks face a different set of constraints and so value unions more highly. It is in this latter sense that preferences shall be referred to here. This preference is usually attributed to the relative freedom from discrimination afforded blacks and others by unions' egalitarian policies. For example, a recent study found no evidence of a racial differential in the impact of unions on opportunities for occupational advance or on job tenure. (Leigh, 1979). This explanation must be tempered by the abundant litigation charging unions with maintaining discriminatory seniority units, although it cannot be denied that unions tend to protect workers from arbitrary treatment at the hands of the employer. Both the NLRB and the courts have upheld the responsibility of unions as exclusive bargaining agents to fairly represent minority and female employees. The 
relative egalitarianism of the union sector has probably diminished over time as conditions have improved in the non-union sector. Recent studies of racial wage discrimination in CPS samples find that the difference between the union and non-union sector has narrowed, largely because of the overriding equalizing force of Title VII. (Freeman and Medoff).

of greater importance perhaps in explaining black preferences is the union wage effect. In 1967, this was greater for black males and for white females than for white males, although black females lagged behind the others. (Ashenfelter, 1973). At this time, black males and white females had more to gain from working in a union plant. The higher return for blacks among experienced men is still observed when probability of selection into the union sample is controlled for. (Leigh, 1980). During the 1974 recession, as the union wage effect for white males increased, this difference narrowed. The ratio of black male to white male union wage effects dropped from a remarkable 2.24 in 1967 to 1.38 in 1975. (Ashenfelter, 1979). Just as striking, during this stagnant period for white male unionization, the proportion of black males organized increased from .32 in 1965 to .37 in 1975, and the proportion of black females unionized increased from .13 to .22. (Ashenfelter, 1979). The substantial increase in black unionization is concentrated between 1970 and 1975, and cannot be explained by changes in the distribution of blacks across occupations or industries. (Holzer). This growth may give some measure of the strong impact of Title VII of the Civil Rights Act of 1964 in allowing biacks to realize their preferences in the job market, a question we hope to shed some light on here.

\section{Empirical Strategy}

To summarize these countervailing forces briefly, the question to be addressed empirically in the next section is whether blacks' stronger preferences for unions outweighs the impact of unions in slowing change in the composition of the workforce. The government's role is expected to be essentially neutral across sectors, and is 
directly controlled for since we know which establishments are federal contractors subject to affirmative action, and which have undergone a compliance review. Bias due to the possible impact of individual establishment effects is guarded against in two ways. First, all regressions control for past establishment employment patterns, and so essentially difference out time invariant individual effects. Secondly, white-collar employment patterns in which the unions have little say, are compared to blue-collar patterns, with the difference attributed to unions. Union effects, as distinct from a generalized preference for unions by any particular demographic group, are tested both by differentiating the union impact on blacks, Hispanics, and females; and by estimating the impact of individual unions.

\section{Section 2. Unions and the Employment of Hispanics, Blacks, and Females}

Unionized establishments exhibit strikingly different employment patterns than non-unionized establishments in the same industry and SMSA. In light of the fact that unions in the manufacturing sector cannot legally control hiring and in light of the prevalent view that they do not directly influence hiring, this is a remarkable finding made more so by the direction of the effect.

Table 1 presents T-tests of the equality across union and non-union establishments of the levels and changes in the racial and sexual composition of the blue-collar workforce between 1974 and 1980 in a longitudinal sample of 1273 California manufacturing establishments with at least one hundred employees each. The characteristics and construction of this new sample are described in the appendix.

Unionized establishments start out in 1974 with a higher representation of black males, $6.6 \%$ compared to $4.9 \%$ for the non-union establishments. More importantly, black males' employment share grows faster in the union sector 5 . It reaches $7.7 \%$ in 1980, compared to $5.3 \%$ among the non-unionized. The rate of change in means is 17 percent in the union sector in just six years, far greater than the 6 percent in the non-union sector. The mean rates of change in both sectors are even greater, 
suggesting that growth in employment share has been relatively greater where that share was initially low 6 .

Comparing the changes in employment patterns of black males to that of Hispanic males, black females, or Hispanic females warns that there can be no simple monolithic explanation of the higher level and faster growth rate of black male employment share in the union sector. Whatever process preferentially sorts black males into union jobs has not similarly affected black females. Hispanic males, or Hispanic females.

Hispanic males do start out with higher representation in the union sector but faster non-union growth renders this difference insignificant by 1980. Female Hispanics are initially significantly more heavily represented in non-union jobs, and this differential grows over time. Black females also start out with greater employment share in the non-union sector, but their growth rates do not differ significantly across sectors. In both sectors, the greatest proportional employment gains are enjoyed by Asians of both sexes, because they begin with such small shares. Asian growth has been significantly greater in the non-union sector. It is also remarkable that between 1974 and 1980 whites lost their majority position in California manufacturing. Their share dropped by 21 percent from .61 to .48 of blue-collar employment. White females share fell faster in the non-union sector. For white males, there is no significant difference in the decline across sectors.

It is important to note that total employment has not increased in the union sector, although smaller plants have grown. Absolute minority and female employment in this sector has grown while white male employment has declined. This finding stands out in view of the commonly held belief about the impact of union seniority ladders on minority and female employees. Last-in first-out would be expected to reduce minority and female share during a recession because these groups typically have lower seniority than white males. The explanation may simply be that California manufac- 
turing did not suffer from a great recession between 1974 and 1980 . In the study sample, employment in the union sector was stable. According to the Department of Labor, total employment in California manufacturing increased by 18 percent between 1974 and 1980, with an insignificant decline between 1979 and 1980, and a 6 percent decline between 1974 and 1975. (Employment and Training Report of the President 1981, Table d-2, p. 230).

California serves as a strong warning against the facile identification of minority with black. Hispanics are the largest minority group in California, constituting 38 percent of blue-collar employment in manufacturing in 1980. This compares with black's 9 percent and Asians' 6 percent, and is not far behind white's 48 percent. Moreover, Hispanics have grown the fastest, increasing their share fully 10 percentage points in just six years from 28 in 1974. This sharp growth has not been accommodated without conflict. The California State President of the Mexican-American Political Association, Julio Calderon, has said that the:

"[Civil Rights movement] has pitted the black community against the Mexican-American community. This may be unspeakable, but to deny that it exists is to put blinders on oneself"' (Oakland Tribune $3 / 24 / 83$ p. A-14)

It must at once be recalled that the dominant pattern we find here is an increase in Hispanic share and a corresponding decrease in white share, alongside a smaller increase in black share.

\section{Log-Odds Estimates}

The basic results found in the means above stand up well in more rigorous tests. The definitions and sample statistics of the variables used in this analysis are given in Table 2. Table 3 presents our central regression results. These are estimates of logodds models, weighted by the establishment's total blue-collar employment, and controlling for past employment share, two or three digit SIC industry, SMSA, and the percent of blue-collar workers who are craft workers. The essential findings here are in 
general not significantly changed by weighting. These regressions also control for establishment size and growth rate, and whether or not the establishment was unionized, part of a multi-plant company, a federal contractor subject to affirmative action in 1974, or reviewed for compliance with affrmative action between 1974 and 1980. With these extensive and detailed controls, black male share still increases significantly faster in the union sector. As can be seen in equation 2 of Table 3 , this difference of 1.3 percentage points is not small. It amounts to 19 percent of their initial share.

The relative size of the union inpact here can best be appreciated by comparing it with that of affirmative action. Equation 2 also shows that the increase in black male employment share is significantly larger among federal contractors subject to affirmative action, and among contractors that are reviewed for compliance?. The impact of unionization is just slightly less than that of undergoing a compliance review, and actually greater than that of being a federal contractor. Before entering into the question of causality, it is remarkable that in the case of California manufacturing unionization appears to act as a more powerful affirmative action program for black males than does the federal affirmative action program itself.

It has often been argued that black males' employment is limited by their lack of skills. It is then worth noting that in this sample their share of blue-collar employment among all males has increased most in craft-intensive work-forces. In addition, the overall importance of growth in facilitating the entry of minorities and females into manufacturing can be seen in the significant negative impact of establishment growth on white male employment, a summary measure.

In contrast to the faster increase in black male employment in the union sector, unionization has had no significant impact on Hispanic male employment, nor on that of black females, white females, or Asian males ${ }^{8}$. If black males' improved employment under unionism were due only to blacks' attitudes toward unions or proximity to 
unionized establishments, or to unionized establishments' employment practices, one might reasonably expect similar patterns among blacks of both sexes, but we find no significant evidence of such a pattern for black females. Black males not only differ from black females, they also differ from Hispanic males. The theory of discrimination that explains why predominantly white unionized establishments should favor the employment of black males, while treating Hispanic males indifferently at best, cannot be a simple one ${ }^{9}$.

The salient finding in this section is that black male employment share has increased faster in the union sector. In the following sections we turn to questions of causality and attempt to determine how much of this difference can be explained by union policy, or by differences in employer or government behavior across sectors.

\section{Section 3. Differences Across Unions}

Unions are not undifferentiated in either their attitudes or their policies toward affirmative action, or in their actual minority and female membership. Because many large unions have organized plants across a number of industries, and because most industries have been organized by a number of unions, it is possible to separate out the impact of individual unions. If there were no significant differences across unions once industry, SMSA, and plant occupational structure were controlled for, that would constitute strong evidence that the swifter expansion of black male employment share in the unionized sector was primarily due to black males' stronger preference for union jobs, rather than to any policy or practice of any individual unions. That does not appear to be the case here. There are significant differences in minority and female employment growth across unions that in a number of cases correspond closely to differences in these unions' public statements on discrimination and affirmative action.

Here only the most striking cases can be alluded to. Union A, long noted for its liberal stance, has been among the most outspoken proponents of equal rights for 
blacks. In contrast to most. AFL unions, Union A accepted and integrated blacks into existing locals as blacks entered this union's primary industry during the depression. In these early years the union was among the pioneers in formally establishing an internal fair employment practices department. While taking a strong stand on civil rights at the national level, Union A has also been a co-defendant in a plethora of Title VII litigation charging that it maintained discriminatory seniority ladders at the local level. It would seem the union had reached only partial accommodation with its black members.

In 1982, Union A held contracts in eight different two-digit SIC industries in California manufacturing. Table 4 shows that both black and Hispanic males have augmented their share of blue-collar employment significantly more in the twenty-five plants organized by Union A than in most other unionized plants. However discriminatory union seniority ladders may have been, they have not discouraged black or Hispanic males from gaining employment. While the average union impact is to raise black male employment share by 1.3 percentage points, the corresponding increase in plants organized by Union $A$ is 2.8 percentage points. For Hispanic males the difference is even greater. Their employment share grows slower, insignificantly, in the union sector as a whole, but grows by 4.1 percentage points in Union A plants. In fact, Union A is the only union with a significant positive impact on Hispanic employment. This reinforces the interpretation of these patterns as directly influenced by union policy rather than just reflecting ethnic group preferences.

Union B's history has been similar in many ways to Union A's. While blacks have long been employed in large numbers in Union B's primary industry, the union has been the target of a large number of Title VII cases charging discriminatory seniority ladders. But once again, black male employment share has grown significantly faster, by two percentage points, than elsewhere in the union sector.

One explanation advanced for blacks' strong preference for union employment is 
that egalitarianism within most unions limits the scope for any discriminatory treatment, including racial discrimination. The multitude of Title VII charges concerning discriminatory promotion ladders at both Union A and B would seem to belie this thesis, but one must consider the alternative. Blacks may prefer a unionized plant not because discrimination is absent, but simply because it is weaker. Moreover, these discriminatory seniority systems have been frequently and successfully attacked in the courts since 1965. At the same time, members of both Union A and B are among the most well paid industrial workers in America. The substantial union wage effect in these unions are likely to be even larger for blacks, and may well outweigh the finer costs of occupational segregation within the plant. Better to ride second class than to walk.

While minority male employment gains at Union A correspond to the union's long liberal history, Union C was prominently known before 1965 for its racially segregated locals. By the late seventies things had changed. Black male employment share in the 57 plants organized by Union C significantly increased by 2.3 percentage points, more than the average of other unions.

At the other extreme are a number of craft oriented unions in which minority and female employment has fallen relative to other union or non-union plants. The exclusionary ethic of these unions appears to carry over and influence employment patterns in manufacturing, where their referral rights are not so strongly established.

The evidence here suggests that an important part of the explanation for the observed patterns of minority and female employment in general, and of the growth of black male share in the union sector in particular, is to be found in the policies and practices of individual unions. This stands out in the contrast between the craftoriented unions which appear to retard minority and female employment, and Union $\mathrm{A}$ which increases black and Fispanic male employment share more so than do other unions. 


\section{Section 4. White Collar Workers in Unionized Establishments}

Establishments hire both white and blue collar workers, but typically it is only the blue collar workers who are unionized, a difference which will be exploited in this section. This institutional fact allows us to test whether the union effect found above is really an establishment effect. The establishments that are unionized may differ in some ways, such as location or skill requirements, that are uncontrolled for, but correlated with unionization. This is a priori unlikely because our controls are quite detailed and include two or three digit SIC industry, SMSA, establishment size and growth, and the proportion of craft workers among the blue-collar. Nevertheless, it cannot be entirely ruled out. While unionization may influence blue-collar employment it is difficult to see how unionization in itself can affect white-collar demograph$\operatorname{ics}^{10}$.

It does. Black males share of white-collar jobs increases significantly faster in unionized establishments, as seen in Table 5. In absolute terms the effect is small, less than a quarter percentage point. However, relative to blacks males' 1974 share of 1.5 percent this is a substantial increase. The interpretation of this estimate is complicated by the further findings in Table 5 that Hispanic males' share also increases significantly faster in the union sector, while white females share increases significantly less ${ }^{11}$. The result for white-collar Hispanic men may be due to stronger affirmative action pressure in favor of Hispanic men in the union sector, particularly for white-collar jobs.

Unionization affects white-collar employment demographics both directly and indirectly through its impact on blue-collar demographies. The tests in Table 5 explicitly control for the indirect path by holding fixed past blue-collar employment share. In every case higher past blue-collar share is significantly correlated with subsequent white-collar share, even conditioning on past white-collar share, SMSA, and industry. This suggests either strong spillover from blue-collar to white-collar or an omitted 
variable such as proximity to minority neighborhoods. The spillover hypothesis is considerably strengthened by observing the same pattern for females, who do not live in ghettos. Taken together, this evidence of spillover and tipping accords with the essentially tribal model of the labor market that informs many of the arguments in favor of affirmative action.

The tests in Table 5 may then qualify the previous findings for black male production workers because the union effects on white-collar demographics persist even when indirect paths through blue-collar employment are controlled for. In other words, black male employment share in unionized establishments has increased in white-collar jobs as well as in blue-collar jobs. It is important to remember that the union effect among white-collar workers is less than that among the blue-collar. Nevertheless, it is possible that unionization is correlated with some uncontrolled for establishment characteristic that favors the growth and not simply the level, of black male employment ${ }^{12}$.

This section has shown that unionized establishments not only employ more black males in blue-collar jobs, to a lesser extent they also employ more black males in white-collar jobs. Part of this effect may be accounted for by spillover from bluecollar demographics, but part remains and may suggest establishment specific effects.

\section{Section 5. Unions and Affirmative Action}

Under most circumstances, unions should retard the progress of minorities and females under affirmative action for reasons that have much to do with unions but little to do with current discrimination. It is well known that unions reduce quits. Lower turnover will in itself reduce the rate of penetration of minorities and females into the workplace, as we shall now prove.

The change in stock is equal to hires less terminations. This identity is:

$$
B_{t}=B_{t-1}+B^{H}-B^{T}
$$


where

$B_{t}=$ stock of blacks in year $t$

$B^{H}=$ total number of blacks hired between $t-1$ and $t$

$B^{T}=$ total number of blacks terminated between $\mathrm{t}-1$ and $\mathrm{t}$

This may also be expressed as:

$$
P_{t} N_{t}=P_{t} N_{t-1}+I H-O T
$$

where

$P_{i}=$ blacks' share of employment stock in year $\mathrm{t}$

$N_{t}=$ total employment stock in year $\mathrm{t}$

$\mathrm{H}=$ blacks' share of hires

$I=$ total hires

$\mathrm{T}=$ blacks' share of terminations

$0=$ total terminations

Dividing through by $N_{t}$ gives the identity in share form:

$$
P_{t}=\lambda P_{t-1}+\alpha H-b T
$$

where

$\alpha=$ the ratio of total hires to total end of year stock

$\mathrm{b}=$ the ratio of total terminations to total end of year stock

$\lambda=1-\alpha+b=\frac{N_{t-1}}{N_{t}}$

The annual change in share of stock is:

$$
P_{t}-P_{t-1}=(\lambda-1) P_{t-1}+\alpha H-b T
$$

with derivatives 


$$
\begin{aligned}
& \frac{d P}{d H}=\alpha \\
& \frac{d P}{d H}=-b
\end{aligned}
$$

An increase in black's share of hires or terminations has a greater impact on black's share of stock the greater is the hire or termination rate respectively.

In theory the impact of affrmative action on protected groups' share of fows and stock could be hidden by disparate turnover rates between union plants and nonunion plants. If $a$ and $b$ are both small (or of similar magnitude), then $\lambda$ is close to 1 and $\lambda^{n}$ is close to 1 . In this case $P_{t}$ changes only slowly from $P_{t-\pi}$. By the same token, firms characterized by high turnover rates can show large improvements in minorities' and females' employment share without large changes in hiring and firing policy. Thus if affirmative action requires equal effort from all firms, rather than equal results, then high turnover firms should be held to higher employment goals along an adjustment path 13 .

For our purposes here, the important point to remember is that the seniority systems that are part and parcel of unionism will tend to freeze the workforce at a plant, a fact which the Supreme Court in its 1977 Teamsters decision has come to accept. When this is combined with the fact that unionized employment did not grow in the study sample, one would expect affirmative action to appear less successful in unionized establishments for two reasons that have nothing to do with discrimination: low turnover and low growth.

On the other hand, we have already seen that while other protected groups have not progressed significantly faster in the union sector, black males have. Black males also start with a higher 1974 share in the union sector. Similarly, while other protected groups have not significantly benefited from affirmative action in California manufacturing, blacks have. One might then reasonably expect two such positives to interact in a larger positive, but this would embody an oversimplified conception of 
how affirmative action works.

The pressures under affrmative action are to remedy underutilization of minorities and females. If black males are relatively overrepresented in the union sector, affirmative action can act to increase black males' overall share while bringing no direct pressure to bear in the union sector. But of course, with a limited supply of blacks, the non-union sector's gain may well be the union sector's loss. This is especially likely to occur if at the same time Hispanics are relatively underrepresented in the union sector. The combined impact of the contract compliance program may then be to substitute Hispanic males for black males in the union sector,

Table 6 tests for such interactions between unionization and affrmative action pressure, and finds significant evidence of a negative interaction only for black males. Black males' employment share increases 3.1 percentage points more in unionized non-contractors than in non-unionized non-contractors. By contrast, this share increases by just 1.1 percentage points in unionized contractors compared to nonunionized contractors. This is balanced by changes in the employment of Hispanic men, where there is a positive interaction between union and contractor status. In the union sector, black males' share decreases by .004 among contractors, while Hispanic males' share increases by .021. Affrmative action does not always and everywhere lead to increases in black employment, nor is it intended to. These estimates suggest that while Hispanic male employment has increased faster under affirmative action in the contractor sector, black male employment has increased slower, if at all. This may reflect to some degree the relative abundance of black males in the union sector, and correspondingly less affirmative action pressure to increase their share. In $1974,6.6$ percent of all employees in the union sector were black males, compared to only 4.9 percent in the non-union sector. While Hispanic males were also relatively abundant in the union sector, the proportionate disparity was not so great, .21 in the union sectors compared to .19 in the non-union sector. A plausible explanation of the 
observed interactions is not in terms of the way unions mediate affirmative action presures, but rather in terms of the different immediate goals toward which that pressure is directed in the union sector ${ }^{14}$. Judged on the evidence among contractors, the union sector appears more concerned with increasing Hispanic male employment than that of black males.

\section{Section 6. Summary and Conclusion}

This paper has presented four main findings.

(1) Black males share of blue-collar employment has increased faster in union plants than in non-union plants in California manufacturing between 1974 and 1980. This indicates that the growth in unionization among blacks is not due simply to different regional or industry growth rates. We find a positive union effect even when industry, region, size, growth, and affirmative action pressure are controlled for. This suggests that the wide precedents set by Title VII of the Civil Rights Act of 1964 has opened doors for blacks to express their preferences in employment.

(2) While union seniority systems force the layoff of low-tenure workers during a recession, the recessions of 1974 and 1979 did not harm minorities and females any more in the union than the non-union sectors, judging on the basis of growth in employment share between 1974 and 1980.

(3) Unionization has no significant impact on blue-collar employment share of other groups, with the exception of a significantly negative impact on Hispanic females. The notion that industrial unions as a whole are any more or less discriminatory is belied by the absence of significant effects for Hispanic males, black females, and whites.

(4) There are significant differences across particular unions within industry and region that correspond with each unions public record of EEO policy and practice. Black male employment increases most in industries with a long history of black employment, in unions that take a liberal position towards EEO, and in industries with 
a large union wage effect. Craft type unions have a negative impact.

Changes in employment share among Hispanics, blacks, Asians, whites, and women are a response to forces on both the supply and demand sides of the market. Unionized establishments in California manufacturing do not exhibit any more discrimination than do non-union establishments against black or Hispanic men, or against black or white women. Title VIl appears to have been effective in increasing employment opportunities for blacks, allowing them to obtain the union jobs they prefer. 


\section{Appendix. Data}

A new and detailed set of information at the establishment level of disaggregation was assembled for this study. EEO-1 reports detailing establishment level demographics were matched for the years 1974 and 1980 to produce a longitudinal file. All of the

data on establishment demographics, occupational structure, employment growth, industry, location, and contractor status comes from this file. This was in turn matched with OFCCP administrative records made available by the OFCCP's Division of Program Analysis to determine which establishments had undergone an aflirmative action compliance review. These reviews essentially count only those performed by the Department of Defense, and so are concentrated in the durable goods manufacturing industries. The characteristics of this EEO sample are discussed in greater detail in other work. From this national longitudinal file, the 1273 establishments in the manufacturing sector in California with more than 100 employees were selected. California, while interesting in its own right, also accounted for $8.9 \%$ of all U.S. manufacturing employment in 1977. For comparison, the 1977 Census of Manufactures counted 3278 California manufacturing establishments with at least 100 employees. Since all of these plants are required by law to file EEO forms, the undercount is significant. Roughly half the EEO sample is lost in the construction of the longitudinal file. A careful study of similar sample attrition by Ashenfelter and Heckman concluded that non-matches were largely random. The remaining undercount is unexplained. While one might imagine that plants with poor EEO records simply do not report, this in itself should not bias our union/non-union comparison.

The union status of each of these establishments was determined by examining the 1982 collective bargaining contract collection of the California State Department of Industrial Relations. The Department has more than 3,400 private-sector agreements on file, and makes intensive efforts to obtain all contracts covering 50 or more employees. In 1982 this file included 1,364 contracts in the manufacturing sector. 
covering 450,310 employees. Since unions never achieve contracts in many plants in which they are certified as exclusive bargaining agents, only plants with collective bargaining agreements will be referred to as unionized in this paper.

The coverage of this file is extensive, especially for contracts covering more than 50 employees. According to the US Department of Labor there were 2,001,000 employees in California manufacturing in 1980. (Employment and Training Report of the President, 1980, table d-2, p. 230). Applying the 1977 California average of 35 percent non-production workers in manufacturing yields 1,300,650 production workers. (U.S. Census of Manufactures, 1977, Vol. III, Geographic Area Series-California, Part I, Table 2b, pp. 5-8.) In a pooled 1973-1975 CPS sample of 6022 private-sector production workers in California, Freeman and Medoff estimate the proportion unionized at .35. close to the national average of 36. (Freeman and Medoff, 1979, p. 166, Table 4). Nationally, Freeman and Medoff report that $49 \%$ of production workers in manufacturing were union members. On this basis, we would expect to find 637,320 union members among production workers in California manufacturing.

88 percent of all employees covered by collective bargaining agreements covering at least 100 workers in California manufacturing are subject to union shop or modified union shop security clauses. (California Department of Industrial Relations, 1982, Table 1). So the contract file then includes about 396,000 union members, or 62 percent of the number we would expect to find by applying the Freeman-Medoff estimates of percent unionized to BLS totals. Part of this discrepancy may be due to the striking decline in unionism in California. Union members as a proportion of all production workers in California manufacturing dropped from .56 in 1975 to .42 in 1979. (California Department of Industrial Relations, 1980, p.2. Table 1). If we adjust Freeman and Medoff's 1973-1975 benchmark downwards by the same 25\% to .37, then we would expect 481,240 union members in California manufacturing. On this basis the contract file includes $82 \%$ of all union members in California manufacturing. The 
remainder are likely to be in establishments of less than 100 employees, which are excluded from the study sample. To the extent that some unionized establishments are still not identified as such, this measurement error will bias our results against finding any difference between the union and non-union sectors. 


\section{NOTES}

1. See Brown for a discussion of recent work in this area.

2. Of course, these clanses are carefully worded to comply both with the closed-shop prohibition and with Title VII, but there is no law against discriminating in favor of friends of union members per se. Obviously, if it happens that all these friends are white males, Title VII comes into play.

3. Note that minorities and females can undercut the union grievance system by taking their case directly to the courts or the EEOC, as established in the case of Alexander v. Gardner-Denver Company, and this internal political consideration may influence unions' attitudes.

4. The law in this area is still developing, and was undergoing significant changes during the period studied. Before 1977 the lower federal courts, most notably in the case of Quarles v. Phillip-Morris, had judged seniority systems that perpetuated the effects of past discrimination to be illegal, and these early decisions may have influenced some of the companies studied here. The blunt edge of these court decisions gave rise in a number of cases to difficult negotiations to reassign seniority rights and redraw seniority units. (Ichniowski). While the EEOC has argued that $703(\mathrm{~h})$ should only apply to collectively bargained seniority systems, one district court has recently extended it to non-union cases. (EEOC vs. E.I. duPont De Nemours \& Co. [D. Del. 1978]).

5. Despite the increase in black male share in the union sector, the percentage of black males who are unionized in the study sample falls slightly from .72 in 1974 to .70 in 1980 because of the faster growth of total employment in the non-union sector. While the number of black males employed in the union sector increased by 17 percent, the number employed in the non-union sector increased by 27 percent. 
8. On the other hand. with finer controis we shall later see contrary evidence show ing tipping.

7. Concerning the impact of affirmative action, in California manufacturing the pro gram has significant impacts on blacks and on white males. Both female and male Dlack employment shares increase significantly faster in establishments that are federal contractors, and at establishments that undergo a compliance review. Although white males' share of total blue-collar employment does increase significantly at contractor establishments, the increase in proportion to initial 1974 share is larger for black males, $19 \%$ compared to $14 \%$, so black males' share of male employment does increase among contractors. The observed pattern for white males is not obviously compatible with an effective affirmative action program, and is anomalous in the sense that it is not generally observed in the economy as a whole. A possible explanation is that since the union and defense contractor sectors tend to be high-wage sectors, white males are relatively slower to leave these sectors than others within manufacturing. The largest minority in California, the Hispanics, have not been greatly affected by affirmative action. Their employment share grows slower at contractors and faster at reviewed contractors, but the effects are not significant. At the same time, white females gained under affirmative action, but not significantly. Blacks may benefit by being both small and vocal. It is more difficult to make room for a large protected group, such as Hispanics or females, and the pressure to accommodate a quieter group may not be great. Questions concerning the impact of affirmative action are the focus of a companion paper.

8. The distribution of each minority group in California is markedly different, and provides useful test variation. These regressions include five SMSA dummies, whose coefficients and selection reflect population demographics. The areas are the Los Angeles SMSA, containing 47 percent of the sample; the combined San 
Diego, Anaheim, and Riverside SMSAs; the San Francisco SMSA, the San Jose SMSA. all other Northern California counties, and all other Southern California counties. Reflecting their respective population concentrations, black employment share increases faster in Los Angeles and San Francisco than elsewhere in California, Hispanic increases faster in Los-Angeles and San-Diego, and Asian increases faster in San Francisco and San Jose.

9. In this regard there are two factors that may help explain the observed pattern for Hispanic males. First, compared to blacks, Hispanics are on average more recent immigrants to California, and a large but unknown fraction are here illegally. They may well be further back in line for union jobs, and the illegals may have greater trepidation and diffculty in obtaining employment at the larger and more formal union establishments. Second, most studies of Hispanic-white earnings ratios have found little evidence of discrimination once language and education are controlled for. (Reimers). If black males are attracted to union shops by the insulation from discrimination they enjoy under the umbrella of union egalitarianism, it is possible that Hispanics may not feel as acute a need for such protection, but this is doubtful. It helps to compare Hispanics with blacks among females. While unionization has had an insignificant positive impact on black females, Hispanic female employment grows significantly slower in the union sector. This is more consistent with the view that Hispanics, as more recent immigrants, are further back in the queue for union jobs. A more closely knit Hispanic family cannot explain the difference in employment across sectors.

10. There are, of course, indirect paths such as the company that promotes from the ranks, or that hires supervisors who match the race or sex of its production workers, who we have found are more likely to be black in the union sector. Alternatively, this could come about through the clustering of blacks in establishments that already employ many blacks. Plants, like neighborhoods, may tip. In 
fact, one of the major arguments in favor of affirmative action rests upon just such externalities: the costs of searching for and obtaining a job are lower if merrbers of one's group are already employed at a given plant. Firms are required to reach out to potential minority and female employees to counteract such clustering among predominant white males. Leaving these indirect, but potentially important, paths aside, we would not expect the presence of a collective bargaining contract among the production workers of a plant to have any impact on the demographic composition of the non-production work-force.

11. These last two patterns for white-collar workers are reversed among blue-collar workers, although the coefficients in the latter case are insignificant. This sign reversal on the union effect between white-collar and blue-collar workers suggests that a simple omitted variable bias story is not likely to explain the union effect on Hispanic males and white females.

12. Since SMSA is controlled for, this would require, for example, that the unionized plants in Los Angeles be closer to Watts and other concentrations of black population than are non-union plants. Since the sample of plants is longitudinal, this cannot simply be due to the establishment of new plants in the suburbs after 1974. Also note that this within SMSA geographic proximity cannot explain why white-collar Hispanic males are more heavily represented at union plants at the same time relative gains for their blue-collar brothers are nowhere to be seen. Moreover, while black male employment has increased relative to that of white males in the union sector, no such effect was observed in Tables 3 among bluecollar females. Unionism is associated with a 5 percent greater employment share for black females, which is less than the 9 percent for white females. It is also interesting to note that a pioneering study of Chicago establishment demographics between 1967 and 1970 also found a positive union effect on growth of black male share even after controlling for distance from black residence area. 
(Burman). To tove another example, since two and sometimes three digit SIC industry is controlled for, along with the percent of craft workers among bluecollar, ard the percent of clerical workers among white-collar, this ornitted variable bias argument would require that the skill requirements of union plants differ in very fine ways that favor blacks not only in blue-collar jobs, but also in white-collar jobs, yet at the same time hinder Hispanic employment. While possible, in my opinion these scenarios are unlikely. The question of geographic proximity is addressed in detail in a companion paper. In a sub-sample of Los Angeles and Orange County establishments, the union effect on both white and blue-collar workers persists even when distance from the ghetto is controlled for. The simplest explanation is that many of the white-collar workers in this sample are in fact unionized, as fully 29 percent of all black male managerial workers were reported to be in 1967. (Ashenfelter, 1973).

13. Affirmative action might be successful in increasing blacks' share of hires, $H$, and reducing their share of terminations, $T$, at union establishments. But since these establishments typically have lower turnover rates $\alpha$ and b than non-union establishments, the change in stock $\Delta P_{t}$ is expected to be lower, masking the impact of affirmative action. Unionized plants are characterized by relatively stable work forces of long tenure. Unless long-tenure jobs are themselves the product of an intention to discriminate, which is unlikely, it is appropriate to judge affrmative action in such stable industries by its impact on minorities' and females' share of new hires and terminations rather than their share of employment. Since the workforces turnover slowly, a positive change in flow shares will have to cumulate for years before it has a significant effect on employment stock shares.

14. Absent strong demonstration effects, that pressure should be most obvious in the case of compliance reviews, but here the interactions terms are insignificant and the evidence inconclusive. 


\section{REFERENCES}

Ashenfelter, Orley, "Racial Discrimination and Trade Unionism", The Journal of Political Economy. 80(May/June 1972), pp. 435-464.

Ashenfelter, Orley, "Discrimination and Trade Unions", in Discrimination in Labor Markets, Orley Ashenfelter and Albert Rees, eds., (Princeton, N.J.: Princeton University Press, 1973), pp. 88-112.

Ashenfelter, Orley, "Union Relative Wage Effects: New Evidence and a Survey of Their Implications for Wage Inflation". in Econometric Contributions to Public Policy, R. Stone and W. Peterson, eds., (New York: St. Martins, 1979).

Block, Richard N, "The Impact of Seniority Provisions on the Manufacturing Quit Rate". Industrial and Labor Relations Review, 31(July 1978), pp. 474-481.

Brown, Charles, "The Federal Attack on Discrimination: The Mouse that Roared?" unpublished paper, 1983.

Burman, George. The Economics of Discrimination: The Impact of Public Policy. unpublished Ph.D. thesis, Graduate School of Business, University of Chicago, 1973.

Farber, Henry and Daniel H. Saks, "Why Workers Want Unions: The Role of Relative Wages and Job Characteristics", Journal of Political Economy. (April 1980), pp. 349-69.

Freeman, Richard B., "The Effect of Unionism on Worker Attachment to Firms", Journal of Labor Research, 1(Spring 1980), pp. 29-62.

Freeman, Richard B., and James Medoff, "New Estimates of Private Sector Unionism" Industrial and Labor Relations Review, 32(January 1979), pp. 147-174.

Freeman, Richard B., and James Medoff, What Do Unions Do? (New York: Basic Books, fortheoming).

Fogel, Walter A., The Negro in the Meat Industry, (Philadelphia: University of Pennsylvania Wharton School of Finance and Commerce, 1970) 
Holzer, Harry, Recent Trends in Labor Union Membership for Blacks, unpublished thesis, Harvard College, 1978.

Ichniowski, Casey, "Have Angels Done More? The Steel Industry Consent Decree", Industrial and Labor Relations Review, 36(January 1983), pp. 182-198.

Kochan, Thomas, How American Workers View Labor Unions Monthly Labor Review, (April 1979), pp. 23-31.

Leigh, Duane E., "Unions and Non-Wage Racial Discrimination", Industrial and Labor Relations Review", 32(July 1979), pp. 435-450.

Leigh, Duane E., "Racial Differences in Union Relative Wage Effects- A Simultareous Equations Approach", Journal of Labor Research, 1(Spring,1980),pp.95-114.

Leonard, Jonathan S., "Anti-Discrimination or Reverse Discrimination: The Impact of Changing Demographics, Title VII and Affrmative Action on Productivity", The Journal of Human Resources, 1984.

Lewis, H. Gregg, Unionism and Relative Wages in the United States, (Chicago: University of Chicago Press, 1963).

Marshall, Ray, The Negro and Organized Labor, (New York: Wiley, 1965).

Medoff, James, "Layoffs and Alternatives Under Trade Unions in United States Manufacturing", American Economic Review, 69(June 1979) pp. 380-395.

Reimers, Cordelia, "Sources of the Wage Gap Between Hispanics and Other White Americans'"', mimeograph, Princeton University, 1980.

State of California, Department of Industrial Relations, "Provisions of California Collective Bargaining Agreements 1981", November 1982.

State of California, Department of Industrial Relations, "Union Labor in California 1979", November 1980.

U.S. Employment and Training Report of the President. (Washington D.C: Government Printing Office, 1981). 

Table 1: T-Tests of Changes in Demographic Proportions of Blue-Collar Fmployment
by Union Status, 1974-1980. N=806 Non-Union and 467 Union Establishments.

\begin{tabular}{|c|c|c|c|c|c|c|c|c|}
\hline \multirow{3}{*}{$\begin{array}{c}\text { Line } \\
1 \\
2 \\
3\end{array}$} & \multirow{3}{*}{$\begin{array}{l}\begin{array}{c}\text { Demographic } \\
\text { Group }\end{array} \\
\text { Black } \\
\text { Males }\end{array}$} & \multirow{3}{*}{$\begin{array}{l}\text { Union } \\
\text { Status } \\
\mathbf{N} \\
\mathbf{Y}\end{array}$} & \multicolumn{2}{|c|}{ Mean $^{1974}$} & \multicolumn{2}{|c|}{1980} & \multirow[b]{2}{*}{ Meand } & \multirow[b]{2}{*}{ Mean $\% \Delta$} \\
\hline & & & Mean & $\sigma$ & Mean & $\sigma$ & & \\
\hline & & & $\begin{array}{l}.049 \\
.066 \\
(3.8)\end{array}$ & $\begin{array}{l}.08 \\
.07\end{array}$ & $\begin{array}{l}.053 \\
.077 \\
(5.6)\end{array}$ & $\begin{array}{l}.07 \\
.08\end{array}$ & $\begin{array}{l}.003 \\
.011 \\
(2.7)\end{array}$ & $\begin{array}{l}28 \\
44 \\
(1.6)\end{array}$ \\
\hline $\begin{array}{l}4 \\
5 \\
6\end{array}$ & $\begin{array}{l}\text { Hispanic } \\
\text { Males }\end{array}$ & $\begin{array}{l}\mathbf{N} \\
\mathbf{Y}\end{array}$ & $\begin{array}{l}.187 \\
.213 \\
(2.4)\end{array}$ & $\begin{array}{l}.19 \\
.18\end{array}$ & $\begin{array}{l}.255 \\
.263 \\
(0.7)\end{array}$ & $\begin{array}{l}.22 \\
.19\end{array}$ & $\begin{array}{l}.067 \\
.049 \\
(2.5)\end{array}$ & $\begin{array}{l}75 \\
47 \\
(1.6)\end{array}$ \\
\hline $\begin{array}{l}7 \\
\mathbf{B} \\
\mathbf{9}\end{array}$ & $\begin{array}{l}\text { Asian } \\
\text { Males }\end{array}$ & $\begin{array}{l}\mathbf{N} \\
\mathbf{Y}\end{array}$ & $\begin{array}{l}.013 \\
.014 \\
(0.6)\end{array}$ & $\begin{array}{l}.02 \\
.02\end{array}$ & $\begin{array}{l}.030 \\
.026 \\
(1.6)\end{array}$ & $\begin{array}{l}.04 \\
.03\end{array}$ & $\begin{array}{l}.017 \\
.012 \\
(2.2)\end{array}$ & $\begin{array}{l}1.31 \\
1.41 \\
(0.4)\end{array}$ \\
\hline $\begin{array}{l}10 \\
11 \\
12\end{array}$ & $\begin{array}{l}\text { White } \\
\text { Males }\end{array}$ & $\begin{array}{l}\mathbf{N} \\
\mathbf{Y}\end{array}$ & $\begin{array}{l}.427 \\
.522 \\
(7.0)\end{array}$ & $\begin{array}{l}.27 \\
.23\end{array}$ & $\begin{array}{l}.332 \\
.428 \\
(6.2)\end{array}$ & $\begin{array}{l}.24 \\
.25\end{array}$ & $\begin{array}{l}-.096 \\
-.093 \\
(0.3)\end{array}$ & $\begin{array}{l}-.18 \\
-.13 \\
(1.1)\end{array}$ \\
\hline $\begin{array}{l}13 \\
14 \\
15\end{array}$ & $\begin{array}{c}\text { Black } \\
\text { Females }\end{array}$ & $\begin{array}{l}\mathbf{N} \\
\mathbf{Y}\end{array}$ & $\begin{array}{l}.020 \\
.016 \\
(1.9)\end{array}$ & $\begin{array}{l}.10 \\
.03\end{array}$ & $\begin{array}{l}.026 \\
.023 \\
(1.2)\end{array}$ & $\begin{array}{l}.06 \\
.04\end{array}$ & $\begin{array}{l}.006 \\
.007 \\
(0.4)\end{array}$ & $\begin{array}{l}.68 \\
1.01 \\
(0.8)\end{array}$ \\
\hline $\begin{array}{l}16 \\
17 \\
18\end{array}$ & $\begin{array}{l}\text { Hispanic } \\
\text { Females }\end{array}$ & $\begin{array}{l}\mathbf{N} \\
\mathbf{Y}\end{array}$ & $\begin{array}{l}.106 \\
.056 \\
(6.3)\end{array}$ & $\begin{array}{l}.15 \\
.05\end{array}$ & $\begin{array}{l}.142 \\
.075 \\
(7.4)\end{array}$ & $\begin{array}{l}.18 \\
.11\end{array}$ & $\begin{array}{l}.037 \\
.019 \\
(3.5)\end{array}$ & $\begin{array}{l}.68 \\
.92 \\
(2.0)\end{array}$ \\
\hline $\begin{array}{l}19 \\
20 \\
21\end{array}$ & $\begin{array}{c}\text { Asian } \\
\text { Females }\end{array}$ & $\begin{array}{l}\mathbf{N} \\
\mathbf{Y}\end{array}$ & $\begin{array}{l}.016 \\
.004 \\
(59.7)\end{array}$ & $\begin{array}{l}.06 \\
.02\end{array}$ & $\begin{array}{l}.028 \\
.009 \\
(57.8)\end{array}$ & $\begin{array}{l}.01 \\
.01\end{array}$ & $\begin{array}{l}.013 \\
.005 \\
(7.8)\end{array}$ & $\begin{array}{l}1.67 \\
1.21 \\
(11.9)\end{array}$ \\
\hline $\begin{array}{l}22 \\
23 \\
24\end{array}$ & $\begin{array}{l}\text { White } \\
\text { Females }\end{array}$ & $\begin{array}{l}\mathbf{N} \\
\mathbf{Y}\end{array}$ & $\begin{array}{l}.176 \\
.100 \\
(7.3)\end{array}$ & $\begin{array}{l}.20 \\
.13\end{array}$ & $\begin{array}{l}.129 \\
.091 \\
(5.1)\end{array}$ & $\begin{array}{l}.14 \\
.11\end{array}$ & $\begin{array}{l}-.046 \\
-.009 \\
(5.9)\end{array}$ & $\begin{array}{l}.17 \\
.40 \\
(2.1)\end{array}$ \\
\hline $\begin{array}{l}25 \\
26 \\
27\end{array}$ & Total & $\begin{array}{l}\mathbf{N} \\
\mathbf{Y}\end{array}$ & $\begin{array}{l}197 \\
381 \\
(6.1)\end{array}$ & $\begin{array}{l}255 \\
789\end{array}$ & $\begin{array}{l}232 \\
381 \\
(4.8)\end{array}$ & $\begin{array}{l}316 \\
774\end{array}$ & $\begin{array}{l}35 \\
0 \\
(2.1)\end{array}$ & $\begin{array}{l}.57 \\
.24 \\
(1.7)\end{array}$ \\
\hline
\end{tabular}

Note: T-Tests across means in parentheses, on every third line. In every case, F-tests reject equality of variances across union and non-union establishments, with more than $99 \%$ confidence. The last column is the mean of percentage changes, not the percentage of change in means, and is calculated
only for those with positive initial share. $\mathrm{N}=$ non-union in 1982. $\mathrm{Y}=$ union in 1982 . 
Table 2: Varáble Definitions, Means, and Standard Deviations. $\mathrm{N}=1273$.

\begin{tabular}{|c|c|c|c|}
\hline $\begin{array}{l}\text { Variable } \\
\text { Name }\end{array}$ & Mean & $\begin{array}{l}\text { Standard } \\
\text { Deviation }\end{array}$ & Definition \\
\hline UNION & .367 & .48 & $\begin{array}{l}=1 \text { if establishment was unionized } \\
\text { in } 1982 .\end{array}$ \\
\hline CONTRACT & .724 & .45 & $\begin{array}{l}=1 \text { if establishment was part of a } \\
\text { contractor company in } 1974 .\end{array}$ \\
\hline REVIEW & .186 & .39 & $\begin{array}{l}=1 \text { if establishment completed a } \\
\text { compliance review between } 1974 \text { and } \\
1980 \text { exclusive. }\end{array}$ \\
\hline SIZE & 264 & 527 & $\begin{array}{l}\text { Total number of blue-collar employees } \\
\text { in } 1974 .\end{array}$ \\
\hline GROWTH & .450 & 3.20 & $\begin{array}{l}\text { Rate of growth of blue-collar } \\
\text { employment from } 1974 \text { to } 1980 .\end{array}$ \\
\hline SINGLE & .280 & .45 & $\begin{array}{l}=1 \text { if establishment was not part of } \\
\text { a multi-establishment company. }\end{array}$ \\
\hline PCRAFT & .248 & .31 & $\begin{array}{l}\text { Proportion of blue-collar employees } \\
\text { who are craftworkers. }\end{array}$ \\
\hline PCLERK & .295 & .14 & $\begin{array}{l}\text { Proportion of white-collar employees } \\
\text { who are clerical workers. }\end{array}$ \\
\hline
\end{tabular}




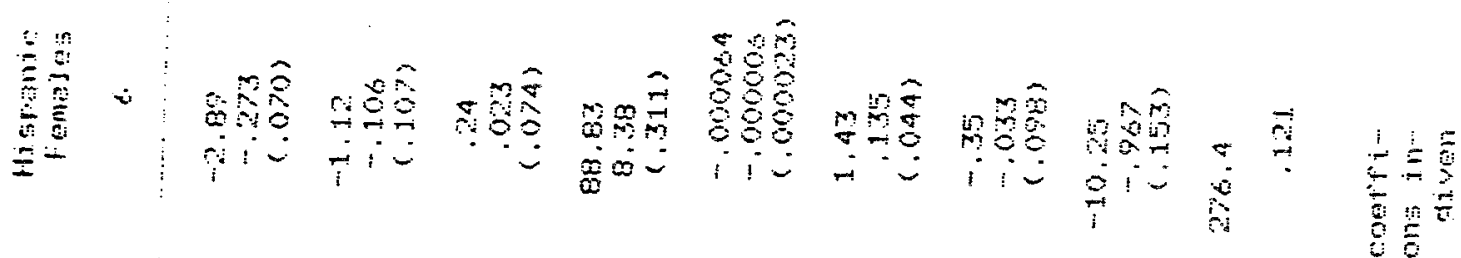

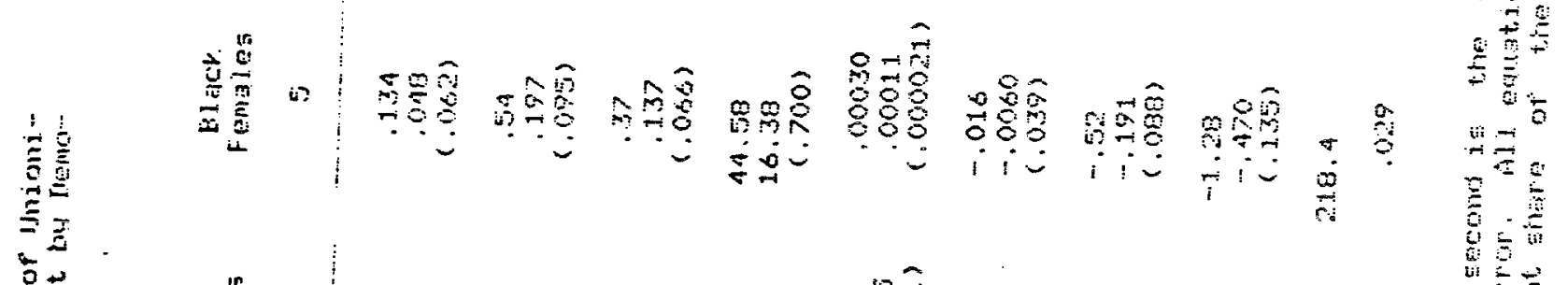

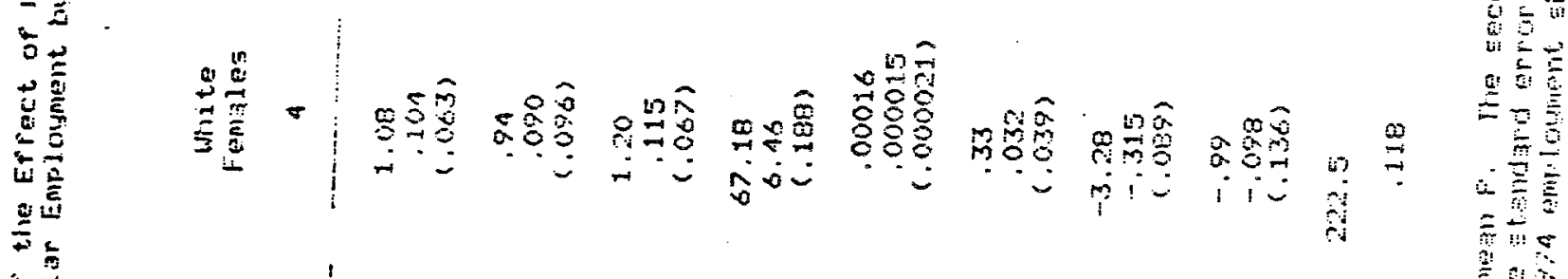

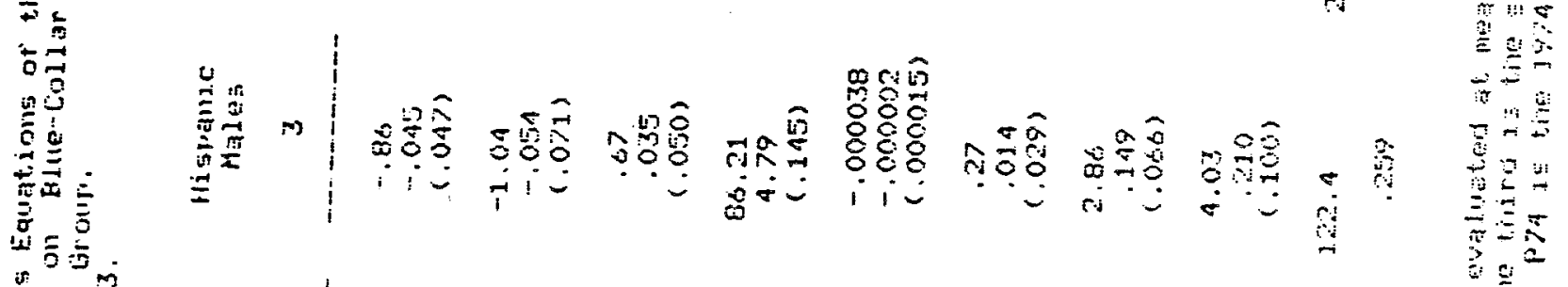

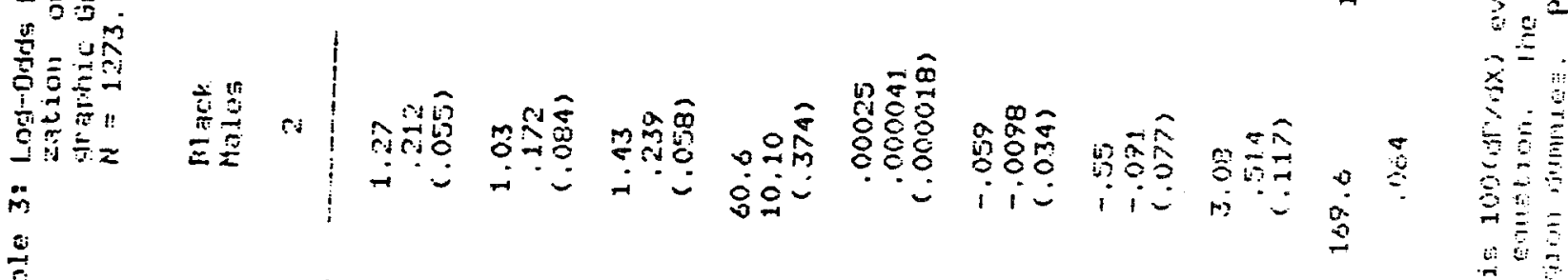

管旁-

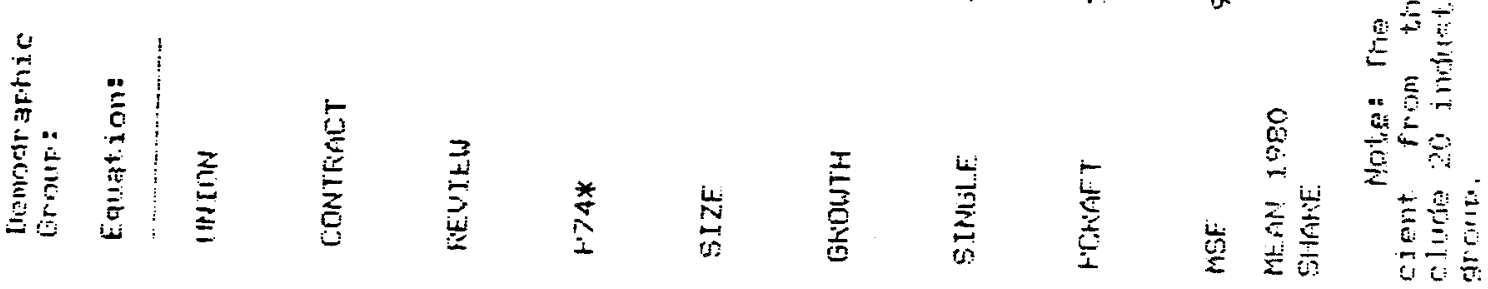


TABLE 4: DIFEERENCES IN DEMOGRAPHIC CHANGES ACROSS UNIONS IN MANUFACTURING $\mathrm{N}=1273$

\begin{tabular}{|c|c|c|c|c|c|c|c|}
\hline \multicolumn{2}{|c|}{$\begin{array}{l}\text { DEMOGRAPHIC } \\
\text { GROUP }\end{array}$} & $\begin{array}{l}\text { WHITE } \\
\text { MALES } \\
\end{array}$ & $\begin{array}{l}\text { BLACK } \\
\text { MULES } \\
\end{array}$ & $\begin{array}{l}\text { HISPANIC } \\
\text { MALES } \\
\end{array}$ & $\begin{array}{l}\text { WHITE } \\
\text { FEIALES } \\
\end{array}$ & $\begin{array}{l}\text { BLACK } \\
\text { FE:LALES } \\
\end{array}$ & $\begin{array}{l}\text { HISPANIC } \\
\text { FEMALES }\end{array}$ \\
\hline UNION & $\underline{N}$ & & & & & & \\
\hline ALL & 466 & $\begin{array}{l}.58 \\
.025 \\
(.041)\end{array}$ & $\begin{array}{l}1.27 \\
.212 \\
(.055)\end{array}$ & $\begin{array}{l}-.86 \\
-.045 \\
(.047)\end{array}$ & $\begin{array}{l}1.08 \\
.104 \\
(.063)\end{array}$ & $\begin{array}{l}.13 \\
.048 \\
(.062)\end{array}$ & $\begin{array}{c}-2.89 \\
-.273 \\
(.070)\end{array}$ \\
\hline A & 25 & $\begin{array}{c}1.42 \\
.061 \\
(.088)\end{array}$ & $\begin{array}{r}2.81 \\
.469 \\
(.117)\end{array}$ & $\begin{array}{l}4.11 \\
.215 \\
(.099)\end{array}$ & $\begin{array}{r}-1.40 \\
-.135 \\
(.133)\end{array}$ & $\begin{array}{l}.60 \\
.215 \\
(.132)\end{array}$ & $\begin{array}{r}-6.42 \\
-.606 \\
(.148)\end{array}$ \\
\hline B & 43 & $\begin{array}{l}5.27 \\
.227 \\
(.105)\end{array}$ & $\begin{array}{l}2.04 \\
.340 \\
(.140)\end{array}$ & $\begin{array}{r}-2.83 \\
-.148 \\
(.120)\end{array}$ & $\begin{array}{c}-3.06 \\
-.294 \\
(.162)\end{array}$ & $\begin{array}{l}-.42 \\
-.150 \\
(.158)\end{array}$ & $\begin{array}{r}-9.54 \\
-.900 \\
(.176)\end{array}$ \\
\hline$C$ & 57 & $\begin{array}{c}1.93 \\
.083 \\
.076\end{array}$ & $\begin{array}{c}2.27 \\
.378 \\
(.100)\end{array}$ & $\begin{array}{r}-1.55 \\
-.081 \\
(.086)\end{array}$ & $\begin{array}{c}1.97 \\
.189 \\
(.116)\end{array}$ & $\begin{array}{l}.50 \\
.177 \\
(.113)\end{array}$ & $\begin{array}{c}-1.45 \\
-.137 \\
(.127)\end{array}$ \\
\hline D & 23 & $\begin{array}{c}2.78 \\
.120 \\
(.184)\end{array}$ & $\begin{array}{r}-1.87 \\
-.312 \\
(.244)\end{array}$ & $\begin{array}{r}-7.49 \\
-.392 \\
(.209)\end{array}$ & $\begin{array}{r}-5.99 \\
-.576 \\
(.280)\end{array}$ & $\begin{array}{l}-.40 \\
-.144 \\
(.276)\end{array}$ & $\begin{array}{r}-1.40 \\
-.132 \\
(.308)\end{array}$ \\
\hline$E$ & 2 & $\begin{array}{r}19.49 \\
.841 \\
(.593)\end{array}$ & $\begin{array}{r}-9.67 \\
-1.611 \\
(.788)\end{array}$ & $\begin{array}{r}-6.78 \\
-.355 \\
(.674)\end{array}$ & $\begin{array}{l}1.44 \\
.138 \\
(.905)\end{array}$ & $\begin{array}{r}-2.56 \\
-.913 \\
(.893)\end{array}$ & $\begin{array}{c}-6.90 \\
-.651 \\
(.994)\end{array}$ \\
\hline$F$ & 3 & $\begin{array}{l}5.8 \\
.250 \\
(.281)\end{array}$ & $\begin{array}{r}-9.60 \\
-1.600 \\
(.373)\end{array}$ & $\begin{array}{c}-9.87 \\
-.517 \\
(.319)\end{array}$ & $\begin{array}{l}3.07 \\
.295 \\
(.429)\end{array}$ & $\begin{array}{r}-5.10 \\
-1.821 \\
(.423)\end{array}$ & $\begin{array}{c}-8.14 \\
-.768 \\
(.471)\end{array}$ \\
\hline
\end{tabular}

Note: The first line is $100(\partial \mathrm{P} / \partial \mathrm{X})$ evaluated at mean $\mathrm{P}$. The second is the coefficient from the log-odds equation. The third is the standard error. ALL is the average union effect from Table 3. The individual union effects are estimated in the same sample with the same additional controls plus twenty union dummies and are relattve to the non-union sector. 


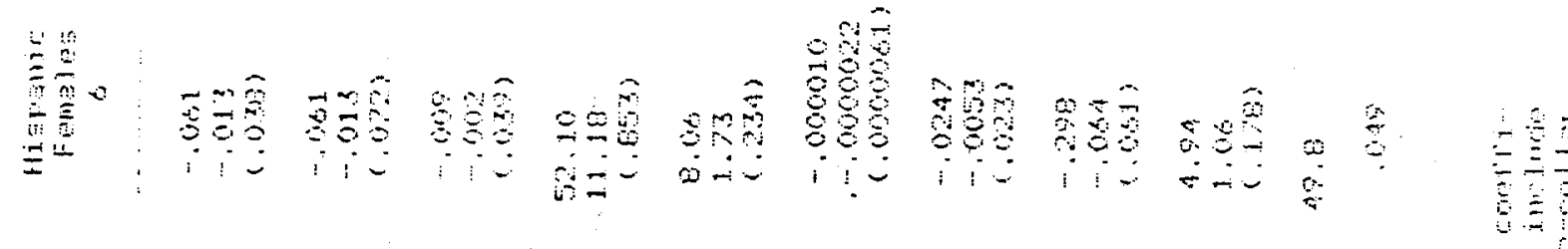

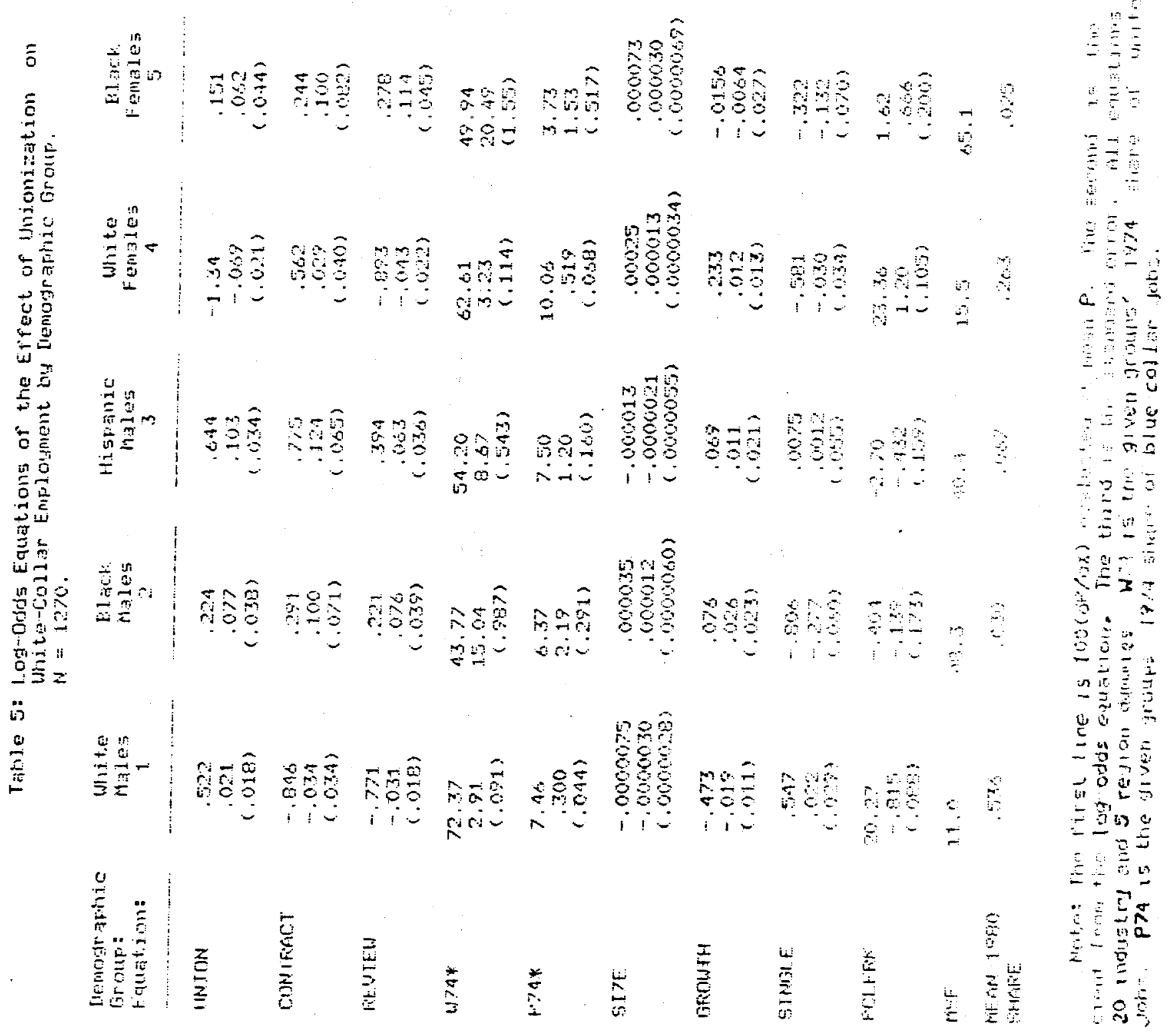


TABLE 6: INTER $\triangle$ CTIONS BETWEEN UNIONS AND AFFIRMATIVE ACTION $\mathrm{N}=1273$

\begin{tabular}{|c|c|c|c|c|c|c|c|}
\hline & & $\begin{array}{l}\text { Mrite } \\
\text { Males } \\
\end{array}$ & $\begin{array}{l}\text { Black } \\
\text { Males }\end{array}$ & $\begin{array}{l}\text { Hispanic } \\
\text { Males } \\
\end{array}$ & $\begin{array}{l}\text { White } \\
\text { Females }\end{array}$ & $\begin{array}{l}\text { Black } \\
\text { Females }\end{array}$ & $\begin{array}{l}\text { Hispanic } \\
\text { Females }\end{array}$ \\
\hline UNION & (U) & $\begin{array}{r}-.231 \\
-.010 \\
(.101)\end{array}$ & $\begin{array}{c}3.04 \\
.506 \\
(.135)\end{array}$ & $\begin{array}{r}-4.97 \\
-.260 \\
(.115)\end{array}$ & $\begin{array}{l}1.11 \\
.107 \\
(.155)\end{array}$ & $\begin{array}{l}.41 \\
.147 \\
(.154)\end{array}$ & $\begin{array}{c}-1.34 \\
-.127 \\
(.173)\end{array}$ \\
\hline CONTRA & CT (C) & $\begin{array}{c}5.61 \\
.242 \\
(.070)\end{array}$ & $\begin{array}{l}1.57 \\
.261 \\
(.094)\end{array}$ & $\begin{array}{r}-2.20 \\
-.115 \\
(.080)\end{array}$ & $\begin{array}{l}.97 \\
.093 \\
(.108)\end{array}$ & $\begin{array}{l}.58 \\
.207 \\
(.107)\end{array}$ & $\begin{array}{l}-.76 \\
-.072 \\
(.120)\end{array}$ \\
\hline REVIEW & $(R)$ & $\begin{array}{l}1.83 \\
.079 \\
(.063)\end{array}$ & $\begin{array}{l}1.56 \\
.260 \\
(.085)\end{array}$ & $\begin{array}{c}.038 \\
.0020 \\
(.072)\end{array}$ & $\begin{array}{l}1.13 \\
.109 \\
(.097)\end{array}$ & $\begin{array}{l}.62 \\
.223 \\
(.097)\end{array}$ & $\begin{array}{l}.77 \\
.073 \\
(.108)\end{array}$ \\
\hline$U \times C$ & & $\begin{array}{l}2.39 \\
.103 \\
(.112)\end{array}$ & $\begin{array}{c}-1.97 \\
-.328 \\
(.150)\end{array}$ & $\begin{array}{c}4.34 \\
.227 \\
(.128)\end{array}$ & $\begin{array}{r}-.080 \\
-.008 \\
(.172)\end{array}$ & $\begin{array}{l}-.16 \\
-.058 \\
(.171)\end{array}$ & $\begin{array}{c}-1.44 \\
-.136 \\
(.192)\end{array}$ \\
\hline$U \times R$ & & $\begin{array}{c}-3.67 \\
-.158 \\
(.081)\end{array}$ & $\begin{array}{l}-.25 \\
-.042 \\
(.108)\end{array}$ & $\begin{array}{l}1.20 \\
.063 \\
(.092)\end{array}$ & $\begin{array}{r}.104 \\
.010 \\
(.125)\end{array}$ & $\begin{array}{l}-.42 \\
-.151 \\
(.124)\end{array}$ & $\begin{array}{l}-.95 \\
-.090 \\
(.138)\end{array}$ \\
\hline$\frac{\partial P 80 *}{\partial C}$ & $\mathrm{u}=0$ & .056 & .016 & -.022 & .010 & -.006 & -.008 \\
\hline$\frac{\partial P 80}{\partial C}$ & $u=1$ & .080 & -.004 & .021 & .009 & .004 & -.022 \\
\hline$\frac{\partial P 80}{\partial R}$ & $\mathrm{u}=0$ & .018 & .016 & .0004 & .011 & .006 & .008 \\
\hline$\frac{\partial P 80}{\partial R}$ & $u=1$ & -.018 & .013 & .012 & .012 & .002 & -.002 \\
\hline
\end{tabular}

Note: These equations are estimated in the same sample and with the same additional controls as Table 3 . $\mathrm{P} 80$ is 1980 share of blue-collar employment of given demographic group. 